\title{
Are the Mathematics Textbooks for Eighth-Grade Meet the Trends in International Mathematics and Science Study (TIMSS) 2019 Mathematics Framework?
}

\author{
Annis Pertiwi ${ }^{1}$, Wahidin $^{1, \text { a) }}$ \\ ${ }^{1}$ Universitas Muhammadiyah Prof. Dr. Hamka \\ Tanah Merdeka Street, Kampung Rambutan, Ciracas, Jakarta Timur, DKI Jakarta, Indonesia, 13830 \\ a)wahidinmtk@uhamka.ac.id
}

\begin{abstract}
This study aims to determine the suitability of mathematics textbooks for eighth-grade with Trends in International Mathematics and Science Study (TIMSS) 2019 Mathematics Framework. This research uses a qualitative research method with a descriptive approach and content analysis techniques. The data of this research are the eighth-grade mathematics textbook. In the textbook analysis, the researcher used three textbooks, namely Penerbit Erlangga, Yudhistira, and the Ministry of Education and Culture (Kemendikbud). The analysis carried out was the analysis of the content domain and knowledge domain based on the TIMSS 2019 Mathematics Framework. The content domain contains numbers, algebra, geometry, and data, and probability. While the knowledge domain contains aspects of understanding, application, and reasoning. In the Penerbit Erlangga book, there are only 2 out of 4 pieces of content contained in TIMSS, while the cognitive domain is 2 out of 3 aspects. Yudhistira book 2 of 4 content contained in TIMSS, while the cognitive domain is 1 of 3 aspects. Kemendikbud's book is 1 of 4 content domains in TIMSS, while the cognitive domain is 1 of 3 aspects. Therefore the three eighth-grade mathematics textbooks as a whole are still not suitable for the TIMSS 2019 Mathematics Framework.
\end{abstract}

Keywords: Mathematics Textbook, TIMSS.

\begin{abstract}
Abstrak. Penelitian ini bertujuan menentukan kecocokan buku ajar matematika kelas VIII dengan Trends in International Mathematics and Science Study (TIMSS) 2019 Mathematics Framework. Penelitian ini merupakan penelitian kualitatif dengan pendekatan deskriptif dan teknik analisis isi. Data yang dianalisis adalah buku ajar matematika kelas VIII. Dalam analisis buku ajar, peneliti menggunakan tiga buku ajar yaitu terbitan Erlangga, Yudhistira, dan Kementerian Pendidikan dan Kebudayaan (Kemendikbud). Analisis dilakukan terhadap content domain dan knowledge domain berdasarkan TIMSS 2019 Mathematics Framework. Content domain terdiri dari bilangan, aljabar, geometri, dan data dan peluang. Sedangkan knowledge domain terdiri dari aspek pemahaman, penerapan dan penalaran. Dalam buku Erlangga, terdapat dua dari 4 content domain, sedangkan cognitive domain hanya 2 dari 3 aspek. Buku Yudhistira memuat 2 dari 4 content domain dan hnaya 1 dari 3 aspek cognitive domain. Pada buku Kemendikbud hanya terdapat 1 dari 4 content domain dan hanya 1 dari 3 aspek cognitive domain. Jadi, tiga buku ajar matematika kelas VIII tersebut secara keseluruhan belum sesuai dengan TIMSS 2019 Mathematics Framework.
\end{abstract}

Kata kunci: Buku Teks Mathematika, TIMSS. 


\section{INTRODUCTION}

General education and specifically science education consider that mathematics education is an important component. It is relevant to compare the other countries' different levels of education which may know student's evaluation and to develop their policies to improve their achievements in science and mathematics (Lessani, Yunus, Tarmiz, \& Mahmud, 2014). Trends in International Mathematics and Science Study (TIMSS) is one of the international evaluation that conducting it. TIMSS is an international assessment of mathematics and science at the fourth and eighth grades that well established as a valuable resource for monitoring educational effectiveness in their education system related to the student's achievement in science and mathematics. TIMSS mathematics assessment framework has two domains, content domains, and cognitive domains. Content domains include several topics and target percentages, there are number 30\%, algebra $30 \%$, geometry $20 \%$, data and probability $20 \%$. The topics and target percentages of cognitive domains are knowing 35\%, applying 40\%, and reasoning 25\% (Martin, 2019).

Indonesia has participated in TIMSS's international study regularly every four years from $1999,2003,2007,2011$, and 2015. Indonesian was ranked $32^{\text {nd }}$ of 38 countries that participated in that study in $1999,37^{\text {th }}$ from 46 countries that participated in that study in $2003,35^{\text {th }}$ from 49 countries that participated in that study in $2007,39^{\text {th }}$ from 43 countries that participated in that study in 2011, and $44^{\text {th }}$ from 49 countries that participated in that study on 2015 (Wahyuningrum, 2017). The results show that Indonesian students' achievements are low ranked.

Textbooks are a primary need in learning and one of media learning which able to increase the effectiveness of learning (Macintyre \& Hamilton, 2010; Hendrice, Valeria, Kurnila, \& Jundu, 2018). Learning can be increased by textbooks which have good quality. We should pick the textbook carefully and we should use it maximally. A textbook is a printed knowledge that plays a significant role in shaping teachers and students (Okeeffe, 2016; Padmawati, 2017). Students can learn the subjects anywhere, not only in school and without teachers teaching them. The intended curriculum and the implemented curriculum are bridged by textbooks, it helps teachers for planning lessons in the class (Jelić \& Đokić, 2017; Reyhani \& Izadi, 2018). TIMSS has a result that when teachers select their teaching method they use mathematics textbooks as their main resource especially for tasks and practice exercises (Gracin, 2018; Yang, 2017).

Badan Standar Nasional Indonesia (BSNP) team who formed by the minister has assessed the textbooks starting from content, language, presentation, and graphics (Padmawati, 2017). The government has provided textbooks that suitable for the current curriculum namely the scientific curriculum with the hope that the students can be more critical in thinking so Indonesia will have better quality in education. However, TIMSS hasn't assessed the textbooks, so the textbooks always change according to the current curriculum. 
The previous research shows a textbook is suitable for algebra and geometry content domains of TIMSS 2019 Mathematics Framework, whereas it isn't suited with number and data and probability content. For the cognitive domains, applying aspects is dominating this textbook (Muawan, 2016). Padmawati, (2017) said that exercises in Buku Ajar Matematika SMP/MTs Kelas IX curriculum 2013 Semester 1 dan 2 are not suitable to cognitive domains of TIMSS 2019 Mathematics Framework. This study aims to determine the suitability of mathematics textbooks for eighth-grade with Trends in International Mathematics and Science Study (TIMSS) 2019 Mathematics Framework based on TIMSS's content domains and cognitive domains.

\section{METHODS}

The study was a qualitative research method with a descriptive approach and content analysis techniques. The objects of this research were eighth-grade mathematics textbooks. The authors used three textbooks, from Penerbit Erlangga, Yudhistira, and the Ministry of Education and Culture (Kemendikbud). In this study, the first instrument was the authors. The textbooks were analyzed through observation and recording. The authors observed the textbooks' suitability with TIMSS 2019 Mathematics Framework, then it was written into the author's notes. The result of the observation and recording was made into a table based on its domains that computed by calculating the percentages. It gets from the percentage of the total of pages that suit to TIMSS 2019 Mathematics Framework divided by the total of all pages in a textbook. From that table, we can find out the suitability of the textbooks and also we may know which textbook is better.

\section{RESULTS AND DISCUSSION}

Penerbit Erlangga textbook has 199 pages in its $1^{\text {st }}$ semester and 231 pages in the $2^{\text {nd }}$ semester, so the Penerbit Erlangga textbook has 450 pages in total for one year. Yudhistira textbook has 245 pages in a year. For the Kemendikbud textbook, it has 252 pages in the $1^{\text {st }}$ semester and 321 pages in the $2^{\text {nd }}$ semester, so the total is 573 pages in a year.

\section{Content Domains}

The three mathematics textbooks had some contents that suitable for to TIMSS 2019 Mathematics Framework, not all of the contents. The results of the analyzed mathematics textbook are presented in Table 1. Table 1 contained the contents of content domains, percentage of each content that showed in textbooks, and TIMSS 2019 Mathematics Framework. From Tabel 1, we can see the comparison of the three mathematics textbooks. 
Table 1. The Result of Content Domains Analysis

\begin{tabular}{|c|c|c|c|c|c|c|c|c|c|c|c|}
\hline \multirow{3}{*}{$\begin{array}{l}\text { Content } \\
\text { Domains }\end{array}$} & \multirow[b]{3}{*}{ Aspects } & \multicolumn{9}{|c|}{ Mathematics Textbook } & \multirow{3}{*}{$\begin{array}{c}\text { TIMSS } \\
2019 \\
(\%)\end{array}$} \\
\hline & & \multicolumn{3}{|c|}{ Penerbit Erlangga } & \multicolumn{3}{|c|}{ Yudhistira } & \multicolumn{3}{|c|}{ Kemendikbud } & \\
\hline & & Pages & $\%$ & $\begin{array}{l}\text { Aver } \\
\text { age } \\
(\%)\end{array}$ & Pages & $\%$ & $\begin{array}{l}\text { Aver } \\
\text { age } \\
(\%)\end{array}$ & Pages & $\%$ & $\begin{array}{l}\text { Aver } \\
\text { age } \\
(\%)\end{array}$ & \\
\hline \multirow{3}{*}{ Number } & Integers & 287 & 67 & \multirow{3}{*}{35} & 145 & 60 & \multirow{3}{*}{32} & 293 & 51 & \multirow{3}{*}{19} & \multirow{3}{*}{30} \\
\hline & $\begin{array}{l}\text { Fractions } \\
\text { and } \\
\text { decimals }\end{array}$ & 135 & 31 & & 78 & 32 & & 31 & 5 & & \\
\hline & $\begin{array}{c}\text { Ratio, } \\
\text { proportion, } \\
\text { and percent }\end{array}$ & 33 & 8 & & 8 & 3 & & 3 & 1 & & \\
\hline \multirow[b]{2}{*}{ Algebra } & Expressions & 93 & 21 & \multirow[b]{2}{*}{14} & 55 & 22 & \multirow[b]{2}{*}{19,5} & 87 & 15 & \multirow[b]{2}{*}{12} & \multirow[b]{2}{*}{30} \\
\hline & $\begin{array}{l}\text { Relationship } \\
\mathrm{s} \text { and } \\
\text { functions }\end{array}$ & 31 & 7 & & 41 & 17 & & 50 & 9 & & \\
\hline Geometry & Geometry & 243 & 57 & 57 & 123 & 50 & 50 & 290 & 51 & 51 & 20 \\
\hline \multirow{2}{*}{$\begin{array}{l}\text { Data and } \\
\text { Probability }\end{array}$} & Data & 29 & 7 & \multirow{2}{*}{8,5} & 22 & 9 & \multirow{2}{*}{7,5} & 44 & 8 & \multirow[b]{2}{*}{7} & \multirow{2}{*}{20} \\
\hline & Probability & 42 & 10 & & 14 & 6 & & 39 & 7 & & \\
\hline
\end{tabular}

Based on Table 1, we knew that the Erlangga textbook had two suitable contents from four contents in content domains they were number content which has 35\% of 30\% of TIMSS 2019 Mathematics Framework's target percentage and geometry content which had 57\% of 20\% target percentage. Both the number and geometry content had suitable content domains in the Erlangga textbook. While for algebra and data and probability content had a lower percentage than the target percentage of TIMSS 2019 Mathematics Framework. Algebra content was 14\% of 30\% and data and probability was $8.5 \%$ of $20 \%$.

Yudhistira textbook also had two contents that suitable to the content domains of the TIMSS 2019 Mathematics Framework. Number content of the Yudhistira textbook was 32\% of 30\% of TIMSS 2019 Mathematics Framework's target percentage, geometry content $50 \%$ of $20 \%$, algebra content $19.5 \%$ of $30 \%$, and data and probability content $7.5 \%$ of $20 \%$. So, number and geometry content was suitable for the content domains of the TIMSS 2019 Mathematics Framework. Whereas algebra and data and probability content were not suitable to the content domains of TIMSS 2019 Mathematics Framework.

Kemendikbud textbook had different results from Penerbit Erlangga and Yudhistira textbook. The geometry content was the only one content that suitable to the content domains of TIMSS 2019 Mathematics Framework's target percentage, it had 51\% of 30\%. The other contents, number contents had $19 \%$ of $30 \%$ of TIMSS 2019 Mathematics Framework's target percentage, algebra $12 \%$ of $30 \%$, and data and probability $7 \%$ of $20 \%$.

From that analysis, geometry content dominates the three textbooks which were above 50\% of the target percentage. Muawan (2016) said that the content of mathematics textbooks was dominated by geometry contents. The second content was number, the third was algebra, and the 
last was data and probability content. The mathematics textbook which had the highest percentage for number content was Penerbit Erlangga also for the geometry and data and probability content. While the mathematics textbook which had the highest percentage for algebra content was Yudhistira.

\section{Cognitive Domains}

Cognitive domains contain knowing aspects, applying aspects, and reasoning aspects. There were some aspects in mathematics textbooks that were not suitable to the cognitive domains of TIMSS 2019 Mathematics Textbook's target percentage. Table 2 presented the result of cognitive domains and the target percentage of cognitive domains.

Table 2. The Result of Cognitive Domains Analysis

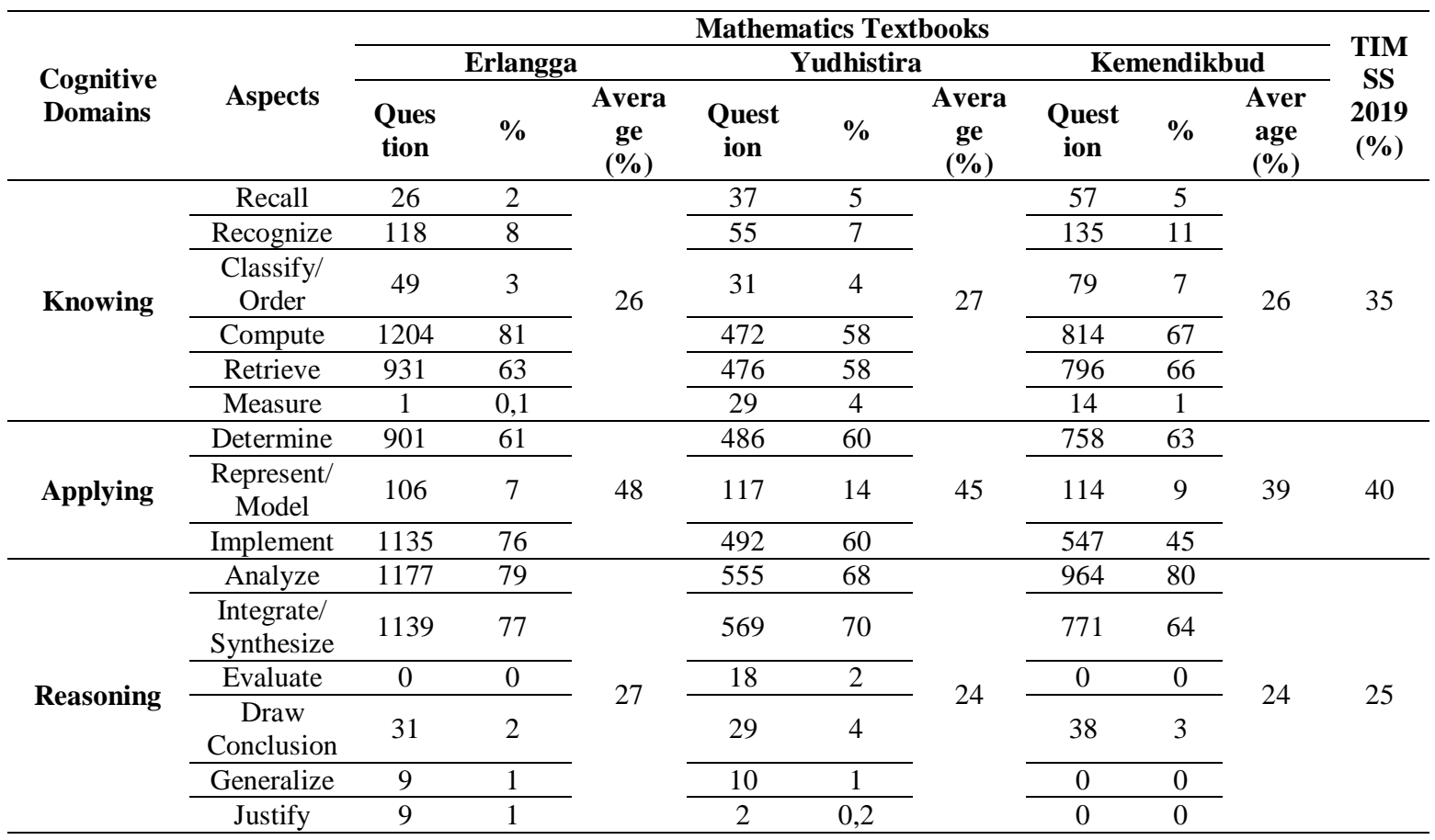

Based on Table 2, it showed that the Erlangga textbook had two aspects that suitable to the cognitive domains of TIMSS 2019 Mathematics Textbook's target percentage. Knowing aspects had $26 \%$ of $35 \%$ target percentage, applying aspects $48 \%$ of $40 \%$, and reasoning aspects $27 \%$ of $25 \%$. So, the two suitable aspects were applying and reasoning aspects.

Yudhistira textbook had one suitable aspect, it was applying aspects which had $45 \%$ of $40 \%$ target percentage. Whereas knowing aspects and reasoning aspects were under the target percentage, knowing aspects were $27 \%$ of $35 \%$ and reasoning aspects were $24 \%$ of $25 \%$. It means that both knowing aspects and reasoning aspects weren't suitable for the target percentage of cognitive domains. 
Kemendikbud's textbook had no suitable aspect. Its knowing aspects had $26 \%$ of $35 \%$ of cognitive domains' target percentage, applying aspects $39 \%$ of $40 \%$, and reasoning aspects $24 \%$ of $25 \%$. The three aspects' percentages were under the cognitive domains' target percentage. The least suitable aspect was knowing aspects. Padmawati (2017) said that knowing aspects were the most aspects that still not suitable for TIMSS's percentage.

From the three aspects, applying aspects had two suitable mathematics textbooks. As Muawan (2016) found that applying aspects had the highest percentage than knowing and reasoning aspects. The mathematics textbook which had the highest percentage for knowing aspects is the Yudhistira textbook. Meanwhile, the highest percentage for applying aspects went to the Erlangga textbook, and the highest percentage for reasoning aspects was the Erlangga textbook too.

\section{CONCLUSIONS}

The textbook of Erlangga has two suitable contents (number contents and geometry contents) from four contents in TIMSS 2019 Mathematics Framework's content domains, whereas algebra contents and data and probability contents are not suitable. While the cognitive domains it has applying and reasoning aspects, whereas knowing aspects is not suitable. Yudhistira two suitable contents (number contents and geometry contents) from four contents in TIMSS 2019 Mathematics Framework's content domains, whereas algebra contents and data and probability contents are not suitable. While the cognitive domains it has applying aspects, whereas knowing and reasoning aspects are not suitable. The Kemendikbud's textbook only has geometry contents that suitable to the TIMSS 2019 Mathematics Framework's content domains and it has no suitable cognitive domains. To maximalize the mathematics textbook the teachers are expected to teach the students to adjust the mathematics subjects based on TIMSS 2019 Mathematics Framework. Besides, the teachers should give the students examples or exercises from other resources to make the students more skilled in knowing, applying, and reasoning aspects. Through analysis and comparison of the textbooks based on TIMSS content can provide writers and curriculum designers to improve the curriculum to facilitate higher achievements in mathematics learning.

\section{REFERENCES}

Gracin, D. G. (2018). International Journal of Mathematical Education in Requirements in mathematics textbooks: A five-dimensional analysis of textbook exercises and examples Requirements in mathematics textbooks : a five-dimensional. 5211. https://doi.org/10.1080/0020739X.2018.1431849

Hendrice, A., Valeria, R., Kurnila, S., \& Jundu, R. (2018). Analisis Kesesuaian Standar Isi Buku Teks Matematika Kelas VIII dengan Kurikulum 2013. 2(November).

Jelić, M., \& Đokić, O. (2017). Towards coherent structure of mathematics textbooks: Analysis of textbooks according to structural blocks of TIMSS research. (May). https://doi.org/10.5937/inovacije1701067J

Lessani, A., Yunus, A. S., Tarmiz, R. A., \& Mahmud, R. (2014). Why Singaporean 8th Grade Students Gain 
EDUMATIKA: Jurnal Riset Pendidikan Matematika

e-ISSN 2620-8911

Volume 3, Nomor 2, November 2020

p-ISSN 2620-8903

Highest Mathematics Ranking in Why Singaporean 8th Grade Students Gain Highest Mathematics Ranking in TIMSS ( 1999-2011 ). (August 2016). https://doi.org/10.5539/ies.v7n11p173

Martin, M. O. (2019). Assessment Frameworks. United States: TIMSS \& PIRLS International Study Center.

Muawan, M. M. (2016). Analisis Kesesuaian Buku Ajar Matematika Kelas VIII SMP dengan Taksonomi TIMSS.

Okeeffe, L. (2016). A Framework for Textbook Analysis. (November). https://doi.org/10.12785/irclr/020101

Padmawati, A. A. (2017). Aspek Kognitif TIMSS pada Soal Latihan Buku Ajar Matematika KelaS IX Kurikulum 2013.

Reyhani, E., \& Izadi, M. (2018). Comparative Content Analysis of Mathematics Textbooks Taught to the First Grade Students of Elementary Schools in Iran, Japan, and America. 10(3), 299-314.

Wahyuningrum, H. (2017). Analisis Materi dan Soal Matematika dalam Buku Tematik Kurikulum 2013 Siswa Sekolah. KNPMP II, 312-324.

Yang, D. (2017). An Analysis of Singaporean versus Indonesian Textbooks Based on Trigonometry Content. 8223(7), 3829-3848. https://doi.org/10.12973/eurasia.2017.00760a 